Chemosphere

November 2018, Volume 211 Pages 449-455

http://dx.doi.org/10.1016/j.chemosphere.2018.07.161

http://archimer.ifremer.fr/doc/00453/56422/

(c) 2018 Elsevier Ltd. All rights reserved.

\title{
Influence of bacteria on the response of microalgae to contaminant mixtures
}

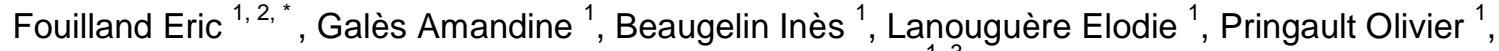 \\ Leboulanger Christophe ${ }^{1,3}$
}

${ }^{1}$ MARBEC, CNRS IRD IFREMER Univ Montpellier, Sète, France

${ }^{2}$ LBE, INRA, Univ Montpellier, Narbonne, France

* Corresponding author : Eric Fouilland, email address : eric.fouilland@cnrs.fr

\begin{abstract}
:
When microalgae are exposed to contaminants, the role of associated bacteria within the phycosphere, the microenvironment surrounding algal cells, remains largely unknown. The present study investigated the importance of algae-associated bacteria on the responses of microalgae growth to metallic and organic toxicant exposure. The effects of a polluted sediment elutriate, and of metal or pesticide mixtures at environmentally relevant concentrations $\left(<10 \mu \mathrm{g} \mathrm{L}^{-1}\right)$ were assessed on the growth of two microalgae strains: Isochrysis galbana, a prymnesiophyte, and Thalassiosira delicatula, a centric diatom. Both cultures were maintained as axenic or bacterized under similar conditions in batch cultures. In axenic conditions, the metal mixture addition at low concentrations alleviated limitation of growth by metals for $T$. delicatula relative to control, but inhibited I. galbana growth at highest concentration. In similar axenic conditions, both T. delicatula and I. galbana growth were negatively inhibited by pesticide mixture at concentrations as low as $10 \mathrm{ng} \mathrm{L}^{-1}$. The bacterial diversities associated with the two microalgae strains were significantly different (Bray-Curtis dissimilarity greater than 0.9) but their impact on microalgae growth was similar. The presence of bacteria reduced algal growth rate by ca. $50 \%$ compared to axenic cultures, whereas no significant effect of sediment elutriate, metal or pesticide mixtures was noticed on non-axenic algal growth rates. These results show that bacteria may have a negative effect on algal growth but can reduce pesticide toxicity or metal availability to algae.
\end{abstract}

\section{Highlights}

- The presence of bacteria in the culture medium negatively affected microalgae growth. The absence of bacteria resulted in short term microalgae response to metals and pesticides at low dose. - Metals and pesticides were not toxic to microalgae when growing with bacteria.

Keywords : Microbial interactions, Metallic and pesticide contaminants, Sediments 


\section{Introduction}

Microalgae as primary oxygen producers in aquatic ecosystems are of prime ecological importance, and represent the first trophic level in the aquatic food web (Azam and Malfatti, 2007; Field et al., 1998). The region surrounding individual algal cells, named the phycosphere, enriched in exuded organic molecules, is considered as an aquatic analogue of the rhizosphere where microorganisms interact with plants in the terrestrial ecosystem (Seymour et al., 2017). Within the phycosphere, microalgae interact with bacteria within a large range from symbiosis to parasitism, conferring advantages or disadvantages to both partners(Bell and Mitchell, 1972). The mechanisms of interactions between bacteria and phytoplankton are diverse and involve specific cellular processes and fine communication (e.g. quorum sensing) (Amin et al., 2012). Such mechanisms may result in antibacterial or algaecide activities (Mu et al., 2007; Ribalet et al., 2008) or substrate competition as experimentally observed between manipulated consortium of microalgae and bacteria (Le Chevanton et al., 2013). On the other hand, the presence of bacteria could offer to microalgae a capacity for tolerance and adaptation to stressful conditions, such as chemical exposure. Indeed, the heterotrophic metabolism of highly diverse bacterial communities in the field and their ability to degrade, metabolize and immobilize a large number of organic and inorganic compounds (Bouwer and Zehnder, 1993; Bruins et al., 2000), make it possible to assign them an ecological role of protecting microalgae, particularly in polluted environments. It can also be hypothesized that microalgal growth may be further improved when the latter are associated with bacteria subjected to chronic contaminants that could develop greater tolerance capacities than naive bacteria and therefore allow microalgae to benefit from these bacterial capacities to cope with pollutants (Bauer et al., 2010). 
Therefore, the main hypothesis tested in this study proposes that the presence of bacteria with degrading or immobilizing ability would reduce the sensitivity of microalgae to organic or metal contaminants, counterbalancing any potential bacterial algaecide activity.

In order to test this hypothesis, the present study focused on the effect of a sediment elutriate issued from the resuspension of polluted sediments on the growth of two microalgae strains commonly found in marine environments: Isochrysis galbana, a small prymnesiophyte, and Thalassiosira delicatula, a centric diatom. Isochrysis galbana is a well-known phytoplankton species, traditionally used in aquaculture and biotechnology due its capacity to produce large biomass (Williams and Laurens, 2010) whereas Thalassiosira delicatula represents a model for diatom study, belonging to a genus widely distributed throughout the world's oceans (Armbrurst et al., 2004). Both strains were growing either in axenic or nonaxenic condition, i.e. associated with bacteria naturally selected during culture selection and maintenance processes. The growth of xenic and axenic strains were compared when exposed to the total (including native bacteria) or dissolved fraction of the resuspended sediment, or artificial mixtures containing either the main metallic or organic contaminants found in these sediments.

\section{Materials and Methods}

\subsection{Elutriate and contaminated artificial mixtures}

\subsubsection{Elutriate and filtered elutriate preparation}

The elutriate was obtained by mixing seawater (3/4 by volume) and sediment (1/4) sampled in February 2015 from the Bizerte Lagoon, for 12 hours, followed by decantation for 
12 hours. The elutriate thus represented the supernatant obtained after decantation. It still contained unsettled particulate matter, resident bacteria and water-soluble contaminants. The filtered elutriate was obtained after filtration of the elutriate on a $0.2 \mu \mathrm{m}$ membrane, leading to a sterile mixture with only the dissolved fraction of chemical compounds. More details on sediment location and sampling can be found in (Pringault et al., 2016).

\subsubsection{Artificial mixture of contaminants}

Two types of artificial mixtures of contaminants were produced in the laboratory, using actual concentrations found after chemical analyses in the elutriate (HydroSciences Montpellier laboratory (HSM) for metals and by the Ecole des Mines d'Alès for pesticides, see (Pringault et al., 2016) for analytical set-up). One of these mixtures contained the organic contaminants, mostly pesticides resulting from the agricultural activity of the Bizerte area, whereas the other mixture contained the metallic fraction resulting from the industrial and harbour activities of the city.

The artificial metal mixture was prepared in Milli-Q water, containing $0.026 \mu \mathrm{g} \mathrm{L}^{-1}$ of cadmium $\mathrm{Cd}, 0.068 \mu \mathrm{g} \mathrm{L}^{-1}$ of copper $\mathrm{Cu}, 0.208 \mu \mathrm{g} \mathrm{L}^{-1}$ of nickel $\mathrm{Ni}, 0.13 \mu \mathrm{g} \mathrm{L}^{-1}$ of lead $\mathrm{Pb}$, $1.615 \mu \mathrm{g} \mathrm{L}{ }^{-1}$ of zinc $\mathrm{Zn}$ and $4.896 \mu \mathrm{g} \mathrm{L}{ }^{-1}$ of arsenic As.

The artificial pesticide mixture was prepared in Milli-Q water with a mixture of the pesticides measured in the elutriate and containing $7.5 \mathrm{ng} \mathrm{L}^{-1}$ of DIA (deisopropylatrazine, an atrazine metabolite), $7.7 \mathrm{ng} \mathrm{L} \mathrm{L}^{-1}$ of DCPU (N-3,4 dichlorophenylurea, a diuron degradation product), $8.8 \mathrm{ng} \mathrm{L}^{-1}$ of diuron, $10.1 \mathrm{ng} \mathrm{L}^{-1}$ of simazine and $12.7 \mathrm{ng} \mathrm{L}^{-1}$ of alachlor. All the pesticides measured in sediment elutriate were herbicides or their degradation products. A concentrated stock solution of both mixtures was performed in order to test a range of mixture concentrations. 


\subsection{Microalgae cultures}

The microalgal strains studied were Isochrysis Galbana (CCAP 927) isolated from a marine fish pond in the British Isles and Thalassiosira delicatula (RCC 2560) isolated from the English Channel. They were grown in a F/2 + Si medium and subjected to light exposure according to a $16 \mathrm{~h} / 8 \mathrm{~h}$ day/night cycle in an incubator maintained at $20^{\circ} \mathrm{C}$ under neon lighting (Vossloh Schwabe ELXe 218.526), providing an average intensity of $100 \mu \mathrm{E} \mathrm{m} \mathrm{m}^{-1}$ (measured with a LI-COR®, Li-1400 equipped with a Walz US-SQS/L spherical micro sensor). The microalgae cultures were inoculated in fresh medium every 2 weeks to maintain active growth before the experiments.

Axenization of cultures was carried out according to the protocol of The Culture Collection of Algae and Protozoa (CCAP) C.N. Campbell (https://www.ccap.ac.uk/knowledgebase.htm) using a mixture of antibiotics (Cefotaxime 500 $\mathrm{mg} \mathrm{L} \mathrm{L}^{-1}$, Carbenicillin $50 \mathrm{mg} \mathrm{L} \mathrm{L}^{-1}$, Kanamycin $200 \mathrm{mg} \mathrm{L}^{-1}$, Augmentin $200 \mathrm{mg} \mathrm{L}^{-1}$ ) at concentrations of 0 to $10 \%$ and with contact times of 24 to 80 hours. The verification of the axenization was carried out by adding 4 ', 6'- $\beta$-diamidino- $\alpha-2-\alpha$-phenylindole (DAPI), filtration and observation under epifluorescence microscopy with UV excitation at $360 \mathrm{~nm}$; spreading in a Petri dish on Marine Broth medium (15\% agar) was also performed. The axeny of microalgae cultures was checked regularly, especially prior to the beginning of the toxicity experiments.

\subsection{Bacterial diversity analysis}

Bacterial 16S rDNA was extracted from $10 \mathrm{~mL}$ of sample filtered on a $0.2 \mu \mathrm{m}$ membrane (PALL Supor® 200 PES), using the DNeasy PowerWater Kit (Qiagen) according to the manufacturer's instructions. 
The V4-V5 region of the $16 \mathrm{~S}$ rRNA gene was amplified over 30 amplification cycles at an annealing temperature of $65^{\circ} \mathrm{C}$, with the forward primer and the reverse primer (Table 1) with their respective linkers. The resulting products were purified and loaded onto the Illumina MiSeq cartridge for sequencing of paired $300 \mathrm{bp}$ reads following manufacturer's instructions (v3 chemistry). Sequencing and library preparation were performed at the Genotoul Lifescience Network Genome and Transcriptome Core Facility in Toulouse, France (get.genotoul.fr).

A modified version of the standard operation procedure for MiSeq data (Kozich et al., 2013) in Mothur version 1.35.0 (Schloss et al., 2009) was used for alignment and as a taxonomic outline. Using Mothur, representative sequences of bacterial operational taxonomic units (OTUs) were identified at the $3 \%$ level.

An $\mathrm{R}$ script was used to perform a hierarchical clustering using $\mathrm{R}$ command hclust with the Bray-Curtis index

\subsection{Experimental design and statistical analysis}

An experimental design has been carried out to study the growth of microalgae in the absence of bacteria (axenic microalgal strains) or in the presence of bacteria (xenic strains with culture associated bacteria) under i) a range of concentrations of a mixture of metals at concentrations found in elutriate $\mathrm{x} 1$, and at greater concentrations: $\mathrm{x} 3, \mathrm{x} 10, \mathrm{x} 31$; and ii) a range of concentrations of a mixture of pesticides at concentrations found in elutriate $\mathrm{x} 1$, and at greater concentrations: x10, x31, x97, x310; iii) the sediment elutriate containing bacteria; iv) the filtered $(0.2 \mu \mathrm{m})$ sediment elutriate; v) culture medium without contaminants (= positive control).

All the tests were carried out in 96-well microplates, 6 replicates were made for artificial mixture treatments, and 12 replicates for controls, elutriate and filtered elutriate 
treatments. Each well $(300 \mu \mathrm{L})$ contained $10 \%$ of microalgae inoculum, 10\% of artificial mixtures or elutriate, and $80 \%$ of culture media. Therefore, the concentrations of elutriate and all the artificial mixtures were diluted to $1 / 10$. The microplates were covered with a BreatheEasy® membrane allowing gas exchange and ensuring an absence of contamination throughout the follow-up of the growth which lasted ten days. This test was carried out for each of the strains (Isochrysis galbana and Thalassiosira delicatula) in axenic and non-axenic conditions. The growth of algal strains was monitored by measuring the optical density at 650 nm every $24 \mathrm{~h}$ until reaching the plateau (i.e. stationary phase) on a Chameleon (Hidex, Finland) microplate reader. The wavelength of $650 \mathrm{~nm}$ was chosen according to previous studies (Ben Othman et al., 2012) corresponding to the absorption peak of chlorophyll pigments with a minimal contribution of bacterial cells to light attenuation. The maximum growth rates were obtained by fitting Verhulst growth curve (see (Fouilland et al., 2014)) to experimental data. An analysis of variance was used to determine the significance of the difference in growth rates between treatments and with or without axenization, followed by a Bonferroni post hoc test using SYSTAT 11 version. Significance threshold was set at $\mathrm{p}<0.05$.

\section{Results and Discussion}

\subsection{Differential sensitivity of axenic microalgal strains to contaminants}

Axenisation of both algal strains was successfully maintained during the present study, as no bacterial cells were observed using epifluorescence microscope and culture techniques performed just before the experiments. A significant reduction in the growth rates of both axenic strains was observed when supplemented with the total elutriate, but not with the filtered elutriate (Fig. 1A). A reduction of light availability due to the presence of large particles in the total elutriate is unlikely as no difference in light absorbance (DO) was 
observed between control (culture media only) and after total elutriate addition (10\% of total well volume) at the beginning of the experiment. This observation suggests that only the particulate fraction of the elutriate containing the bacterial community can affect the growth of both algal strains. The potential negative effect of bacteria presence in the elutriate on the algal growth is supported by the results obtained with xenic microalgae as discussed below.

When comparing the responses of the two axenic microalgae strains tested in the present study, Thalassiosira delicatula showed a higher sensitivity to metal and pesticide additions compared to Isochrysis galbana. Growth rates of T. delicatula increased by $40 \%$ when low concentrations of metals were added to their media corresponding to $\mathrm{x} 1$ and $\mathrm{x} 3$ of the concentrations measured in the elutriate (Fig. 1A). A reduction of $60 \%$ of $T$. delicatula growth rates was observed for all the pesticide concentrations tested except the one corresponding to the pesticide concentration measured in the elutriate (x1). The growth rates of I. galbana were more slightly modified and only at higher concentrations of the metal or pesticide mixture (Fig. 1A). These results suggest that the additions of the metal mixture at low concentrations relieved a growth limitation by metal ions for $T$. delicatula in culture rather than a growth inhibition, while the growth of I. galbana was significantly inhibited at the highest concentration of the metal mixture tested (x31). Arsenic, lead, nickel and cadmium are not normally present in the $\mathrm{F} / 2$ culture media, amongst them only cadmium at low concentrations was found in the literature to induce growth enhancement in diatoms (Lee et al., 1995; Masmoudi et al., 2013). On the other hand, T. delicatula was negatively affected by the pesticide mixture in a magnitude greater than observed for I. galbana (Fig. 1A). Previous studies highlighted the interspecific difference in toxicity of various pesticides on marine algal growth rates (Staley et al., 2015; Walsh, 1972) at $\mathrm{mg} \mathrm{L}^{-1}$ scale, but no conclusive evidences were generally provided regarding the phylogenetic importance in the tolerance or sensitivity of microalgae species. Our results suggest that the diatom T. delicatula and the 
prymnesiophyte I. galbana can be negatively inhibited by exposure to a mixture of pesticides at concentrations as low as $10 \mathrm{ng} \mathrm{L}^{-1}$, the diatom being even more sensitive than the prymnesiophyte, confirming what has been observed in oceanic and coastal phytoplankton strains (Huertas et al., 2010).

Therefore, the lack of effect, or the positive effect, of metal and pesticide mixtures on microalgal growth at concentrations found in elutriate (x1) may explain why microalgae growth was not affected when supplemented with filtered elutriate containing both contaminants. This is also consistent with the absence of any toxic effect observed during a previous experiment performed using a filtered sediment elutriate from Bizerte Lagoon and added to a natural phytoplankton community (Ben Othman et al., 2017).

\subsection{Bacteria affect algal growth rates and algal sensitivity to contaminants}

For both microalgae strains studied here, the presence of bacteria did significantly reduce their growth rate by $c a$. $50 \%$, from 0.8 to $0.4 \mathrm{~d}^{-1}$ for Isochrysis galbana and from 0.9 to $0.5 \mathrm{~d}^{-1}$ for Thalassiosira delicatula (Table 2) in control conditions. This suggests that bacteria i) may act as competitors for nutrient resources and/or ii) may release toxic compounds partially inhibiting, algal growth rates (Mayali and Azam, 2004). This would explain the reduction in the growth rate for axenic strains in the presence of total elutriate containing bacteria. Competition for nutrients is unlikely in the present study, as both bacteria and microalgae were growing in high macro- and micronutrient culture media and the maximal growth rates of microalgae are calculated using the first 2-3 days of the growing phase. The algal growth inhibition by the presence of bacteria seems not to be related to a specific bacterial diversity associated with the microalgae, as the bacterial community was rather different between the two strains (Bray-Curtis dissimilarity greater than 0.5), being dominated by the class of Flavobacteria for Thalassiosira delicatula, and the class of Alpha- 
and Betaproteobacteria for Isochrysis galbana (Fig. 2). This is further supported by the growth reduction of both axenic microalgae strains when supplemented with the elutriate containing a diverse bacterial community (Fig. 2). The additional presence of bacteria from elutriate in the xenic culture of both strains did not lead to an extra reduction in their growth (Fig. 1B) relative to the controls. We therefore suggest that bacteria growing with microalgae strains are probably opportunistic bacteria that benefit from the microalgae phycosphere but to the detriment of algal growth. This is supported by a recent study showing that all the bacteria isolated from a marine algal culture collection had a negative effect on the growth rate of Dunaliella sp. when experimentally associated with the axenic microalgae, even when these bacteria were initially isolated from Dunaliella cultures (Le Chevanton et al., 2013).

Interestingly, in contrast to the observations made under axenic algal growth conditions, in the presence of bacteria, neither microalgal strain was significantly affected by either the metal or pesticide mixture (Fig. 2B). This suggests that even if bacteria may have an algaecide effect, they can also reduce toxicity or metal availability to algae (e.g. pesticide degradation, metal immobilization). For example, $T$. delicatula under pesticide mixtures showed growth rates as low as $0.3 \mathrm{~d}^{-1}$ without bacteria but always greater than $0.5 \mathrm{~d}^{-1}$ with bacteria (Table 2). It seems that the reduction of $c a .50 \%$ of algal growth rate with the presence of bacteria allowed microalgae to better resist pesticide contamination. A reduction in toxicity by bacteria may be suggested, although further investigation is required to clearly evidence their ability to degrade or immobilize these toxic compounds within the 2--3 days of the microalgae growing phase. The herbicides and degradation products included in the mixture assayed during this work are considered as being resistance to rapid biodegradation, and half-lives are often comprised of between a week and a few months. For example, atrazine and degradation products lasted more than a month in marine sediments (Smalling and Aelion, 2006), whereas simazine degradation was only observed with selected bacterial 
strain supplemented with carbon sources (Liu et al., 2018). Diuron and its metabolites exhibited half-lives of longer than five days in selected bacterial pure cultures (Villaverde et al., 2017), and it took more than 100 days to degrade alachlor in artificial wetlands (Elsayed et al., 2015). As a consequence, it appears unlikely that significant degradation of the pesticide mixture occurred within the duration of the present experiment.

We also suggest that the presence of bacteria would induce microalgae to dedicate parts of their resources to defense rather than growth, such as the release of molecules with a high adsorption capability allowing them to cope with all other stressing factors, including toxic compounds. Such a strategy can be seen as a growth-defense trade-off, similar to the phenomenon that was first observed in forestry studies of plant-insect interactions. This trade-off strategy is based on the assumption that plants possess a limited pool of resources that can be invested either in growth or in defense (Coley et al., 1985). A similar strategy was evidenced for microalgae associated with inducible defenses against predators (Zhu et al., 2016) but never suggested when in interaction with bacteria, as far as we know.

The present study clearly shows that interactions between bacteria and phytoplankton can influence the sensitivity of microalgae to toxic compounds and to metal availability. Theses interactions did not seem to be species dependent, as they were not related to the bacterial community composition or phytoplankton species. This suggests that the influence of bacteria on algal sensitivity to contaminants could be generalized to various species of microalgae and bacteria. Such results can be applied for bioremediation of toxic contaminants in heavily polluted environments or as wastewater final treatment. These purposes will benefit from innovative approaches such as the design and the use of artificially optimised microbial consortia to remediate toxic chemicals. Microalgae-bacteria consortia can favour the presence of cometabolism which is recognized as a successful bioremediation approach to biodegrade 
recalcitrant molecules (Hazen, 2010). But further studies are required to assess the degradation and/or immobilization of pesticide and metal compounds by bacteria communities usually observed within the phycosphere and to evidence any change in the metabolism and physiology of microalgae (e.g. release of scavenging molecules) when in the presence of bacteria. This study was performed under nutrient replete conditions but additional investigations would be necessary to explore any change in the bacteria-microalgae relationships when exposed to nutrient limitation in addition to contaminants. Such limitation may affect algal growth in a stronger extent than toxic compounds, further limiting the potential protective effect of bacteria.

\section{Acknowledgments}

We would like to thank the two reviewers for their constructive comments. This study was supported by the RISCO and PHYCOVER projects, which were funded by the French National Agency for Research (respectively, ANR-13-CESA-0001 and ANR-14-CE040011). We should like to thank Chrystelle Bancon-Montigny (UMR 5559 HydroSciences Montpellier) and Catherine Gonzalez (Ecole des Mines d'Alès, Alès), for providing the analyses and the artificial mixtures of pesticides and metals used in this study.

\section{References}

Amin, S.A., Parker, M.S., Armbrust, E.V., 2012. Interactions between diatoms and bacteria. Microbiol. Mol. Biol. Rev. 76, 667-84. https://doi.org/10.1128/MMBR.00007-12

Armbrust, E.V., Berges, J.A., Bowler, C., Green, B.R., Martinez, D., Putnam, N.H., et al. 2004. The genome of the diatom Thalassiosira pseudonana: Ecology, evolution, and 
metabolism. Science 306, 79-86.

Azam, F., Malfatti, F., 2007. Microbial structuring of marine ecosystems. Nat. Rev. Microbiol. 5, 966-966. https://doi.org/10.1038/nrmicro1798

Bauer, N., Grossart, H., Hilt, S., 2010. Effects of bacterial communities on the sensitivity of the phytoplankton Stephanodiscus minutulus and Desmodesmus armatus to tannic acid. Aquat. Microb. Ecol. 59, 295-306. https://doi.org/10.3354/ame01402

Bell, W., Mitchell, R., 1972. Chemotactic and growth responses of marine bacteria to algal extracellular products. Biol. Bull. 143, 265-277. https://doi.org/10.2307/1540052

Ben Othman, H., Leboulanger, C., Le Floc'h, E., Hadj Mabrouk, H., Sakka Hlaili, A., 2012. Toxicity of benzo(a)anthracene and fluoranthene to marine phytoplankton in culture: does cell size really matter?J. Hazardous Mater. 243, 204-2011.

Ben Othman, H., Pringault, O., Louati, H., Sakka Hlaili, A., Leboulanger, C., 2017. Impact of contaminated sediment elutriate on coastal phytoplankton community (Thau lagoon, Mediterranean Sea, France). J. Exp. Mar. Bio. Ecol. 486, 1-12. https://doi.org/10.1016/J.JEMBE.2016.09.006

Bouwer, E.J., Zehnder, A.J.B., 1993. Bioremediation of organic compounds — putting microbial metabolism to work. Trends Biotechnol. 11, 360-367. https://doi.org/10.1016/0167-7799(93)90159-7

Bruins, M.R., Kapil, S., Oehme, F.W., 2000. Microbial Resistance to Metals in the Environment. Ecotoxicol. Environ. Saf. 45, 198-207. https://doi.org/10.1006/EESA.1999.1860

Coley, P.D., Bryant, J.P., Chapin, F.S., 1985. Resource Availability and Plant Antiherbivore Defense. Science (80-. ). 230, 895-899. https://doi.org/10.1126/science.230.4728.895 
Elsayed, O.F., Maillard, E., Vuilleumier, S., Millet, M., Imfeld, G., 2015. Degradation of chloroacetanilide herbicides and bacterial community composition in lab-scale wetlands. Sci. Total Environ. 520, 222-231. https://doi.org/10.1016/j.scitotenv.2015.03.061

Field, C.B., Behrenfeld, M.J., Randerson, J.T., Falkowski, P., 1998. Primary production of the biosphere: integrating terrestrial and oceanic components. Science 281, 237-40. https://doi.org/10.1126/SCIENCE.281.5374.237

Fouilland, E., Vasseur, C., Leboulanger, C., Le Floc’h, E., Carré, C., Marty, B., Steyer, J.-P., Sialve, B., 2014. Coupling algal biomass production and anaerobic digestion: Production assessment of some native temperate and tropical microalgae. Biomass and Bioenergy 70, 564-569. https://doi.org/10.1016/J.BIOMBIOE.2014.08.027

Hazen, T., 2010. Cometabolic Bioremediation. In: Timmis KN (Eds), Handbook of Hydrocarbon and Lipid Microbiology. Springer, Berlin. pp 2505-2514.

Huertas, I.E., Rouco, M., López-Rodas, V., Costas, E., 2010. Estimating the capability of different phytoplankton groups to adapt to contamination: herbicides will affect phytoplankton species differently. New Phytol. 188, 478-487. https://doi.org/10.1111/j.1469-8137.2010.03370.x

Kozich, J.J., Westcott, S.L., Baxter, N.T., Highlander, S.K., Schloss, P.D., 2013. Development of a dual-index sequencing strategy and curation pipeline for analyzing amplicon sequence data on the MiSeq Illumina sequencing platform. Appl. Environ. Microbiol. 79, 5112-20. https://doi.org/10.1128/AEM.01043-13

Le Chevanton, M., Garnier, M., Bougaran, G., Schreiber, N., Lukomska, E., Bérard, J.-B., Fouilland, E., Bernard, O., Cadoret, J.-P., 2013. Screening and selection of growthpromoting bacteria for Dunaliella cultures. Algal Res. 2, 212-222. https://doi.org/10.1016/J.ALGAL.2013.05.003 
Lee, J.G., Roberts, S.B., Morel, F.M.M., 1995. Cadmium: A nutrient for the marine diatom Thalassiosira weissflogii. Limnol. Oceanogr. 40, 1056-1063. https://doi.org/10.4319/lo.1995.40.6.1056

Liu, J., Pan, D., Wu, X., Chen, H., Cao, H., Li, Q.X., Hua, R., 2018. Enhanced degradation of prometryn and other s-triazine herbicides in pure cultures and wastewater by polyvinyl alcohol-sodium alginate immobilized Leucobacter sp. JW-1. Sci. Total Environ. 615, 78-86. https://doi.org/10.1016/j.scitotenv.2017.09.208

Masmoudi, S., Nguyen-Deroche, N., Caruso, A., Ayadi, H., Morant-Manceau, A., Tremblin, G., Martine, M., Schoefs, B., 2013. Cadmium, Copper, Sodium and Zinc Effects on Diatoms: from Heaven to Hell — a Review. Cryptogam. Algol. 34, 185-225. https://doi.org/10.7872/crya.v34.iss2.2013.185

Mayali, X., Azam, F., 2004. Algicidal Bacteria in the Sea and their Impact on Algal Blooms1. J. Eukaryot. Microbiol. 51, 139-144. https://doi.org/10.1111/j.15507408.2004.tb00538.x

Mu, R., Fan, Z., Pei, H., Yuan, X., Liu, S., Wang, X., 2007. Isolation and algae-lysing characteristics of the algicidal bacterium B5. J. Environ. Sci. (China) 19, 1336-40.

Pringault, O., Lafabrie, C., Avezac, M., Bancon-Montigny, C., Carre, C., Chalghaf, M., Delpoux, S., Duvivier, A., Elbaz-Poulichet, F., Gonzalez, C., Got, P., Leboulanger, C., Spinelli, S., Sakka Hlaili, A., Bouvy, M., 2016. Consequences of contaminant mixture on the dynamics and functional diversity of bacterioplankton in a southwestern Mediterranean coastal ecosystem. Chemosphere 144, 1060-1073. https://doi.org/10.1016/J.CHEMOSPHERE.2015.09.093

Ribalet, F., Intertaglia, L., Lebaron, P., Casotti, R., 2008. Differential effect of three polyunsaturated aldehydes on marine bacterial isolates. Aquat. Toxicol. 86, 249-255. 
https://doi.org/10.1016/J.AQUATOX.2007.11.005

Schloss, P.D., Westcott, S.L., Ryabin, T., Hall, J.R., Hartmann, M., Hollister, E.B., Lesniewski, R. a, Oakley, B.B., Parks, D.H., Robinson, C.J., Sahl, J.W., Stres, B., Thallinger, G.G., Van Horn, D.J., Weber, C.F., 2009. Introducing mothur: open-source, platform-independent, community-supported software for describing and comparing microbial communities. Appl. Environ. Microbiol. 75, 7537-41. https://doi.org/10.1128/AEM.01541-09

Seymour, J.R., Amin, S.A., Raina, J.B., Stocker, R., 2017. Zooming in on the phycosphere: The ecological interface for phytoplankton-bacteria relationships. Nat. Microbiol. 2. https://doi.org/10.1038/nmicrobiol.2017.65

Smalling, K.L., Aelion, C.M., 2006. Biological and chemical transformation of atrazine in coastal aquatic sediments. Chemosphere 62, 188-196.

https://doi.org/10.1016/j.chemosphere.2005.05.042

Staley, Z.R., Harwood, V.J., Rohr, J.R., 2015. A synthesis of the effects of pesticides on microbial persistence in aquatic ecosystems. Crit. Rev. Toxicol. 45, 813-836. https://doi.org/10.3109/10408444.2015.1065471

Villaverde, J., Rubio-Bellido, M., Merchán, F., Morillo, E., 2017. Bioremediation of diuron contaminated soils by a novel degrading microbial consortium. J. Environ. Manage. 188, 379-386. https://doi.org/10.1016/j.jenvman.2016.12.020

Walsh, G., 1972. Effects of herbicides on photosynthesis and growth of marine unicellular algae. Hyacinth Control J.

Williams, P.J.le B., Laurens, L.M.L., 2010. Microalgae as biodiesel \& biomass feedstocks: Review \& analysis of the biochemistry, energetics \& economics. Energ. Environ. Sci. 3, $554-590$. 
Zhu, X., Wang, J., Chen, Q., Chen, G., Huang, Y., Yang, Z., 2016. Costs and trade-offs of grazer-induced defenses in Scenedesmus under deficient resource. Sci. Rep. 6, 22594. https://doi.org/10.1038/srep22594 
Table 1. 16S rRNA gene sequencing primers

\begin{tabular}{ll}
\hline forward & 5'-CTTTCCCTACACGACGCTCTTCCGATCTGTGYCAGCMGCCGCGGTA-3' \\
primer & \\
\hline reverse & 5'-GGAGTTCAGACGTGTGCTCTTCCGATCTCCCCGYCAATTCMTTTRAGT-3' \\
primer & \\
\hline
\end{tabular}


Table 2. Growth rates (mean and standard error - SE) of axenic and xenic algal strains measured with or without (control) the addition of total elutriate, filtered elutriate, mixture of metals and pesticides at concentrations from those found in elutriate (x1) to x 31 for metals and $\mathrm{x} 310$ for pesticides. Greyed values represent significant differences with Control $(\mathrm{p}<0.05)$

\begin{tabular}{|c|c|c|c|c|c|c|c|c|c|}
\hline & & \multicolumn{4}{|c|}{ Isochrysis galbana } & \multicolumn{4}{|c|}{ Thalassiosira delicatula } \\
\hline & & \multicolumn{2}{|c|}{ axenic } & \multicolumn{2}{|c|}{ xenic } & \multicolumn{2}{|c|}{ axenic } & \multicolumn{2}{|c|}{ xenic } \\
\hline & & mean & SE & mean & SE & mean & SE & mean & SE \\
\hline \multirow{2}{*}{\multicolumn{2}{|c|}{$\begin{array}{c}\text { Control } \\
\text { total elutriate }\end{array}$}} & 0.83 & 0.04 & 0.38 & 0.03 & 0.92 & 0.09 & 0.54 & 0.05 \\
\hline & & 0.40 & 0.03 & 0.31 & 0.02 & 0.54 & 0.02 & 0.51 & 0.04 \\
\hline \multicolumn{2}{|c|}{ filtered elutriate } & 0.72 & 0.03 & 0.43 & 0.02 & 0.72 & 0.03 & 0.51 & 0.02 \\
\hline \multirow{4}{*}{ metal mixture } & $\mathrm{x} 1$ & 0.98 & 0.13 & 0.38 & 0.04 & 1.28 & 0.05 & 0.71 & 0.02 \\
\hline & $\mathrm{x} 3$ & 0.84 & 0.04 & 0.37 & 0.01 & 1.28 & 0.06 & 0.71 & 0.02 \\
\hline & $\mathrm{x} 10$ & 0.84 & 0.07 & 0.37 & 0.02 & 1.21 & 0.03 & 0.63 & 0.01 \\
\hline & $\mathrm{x} 31$ & 0.58 & 0.04 & 0.35 & 0.04 & 1.09 & 0.18 & 0.48 & 0.02 \\
\hline \multirow{5}{*}{ pesticide mixture } & $\mathrm{x} 1$ & 0.68 & 0.05 & 0.31 & 0.02 & 0.62 & 0.02 & 0.52 & 0.10 \\
\hline & x10 & 0.60 & 0.04 & 0.33 & 0.01 & 0.35 & 0.06 & 0.63 & 0.02 \\
\hline & x31 & 0.49 & 0.05 & 0.30 & 0.02 & 0.39 & 0.12 & 0.58 & 0.03 \\
\hline & x97 & 0.37 & 0.03 & 0.32 & 0.02 & 0.32 & 0.08 & 0.53 & 0.01 \\
\hline & x310 & 0.38 & 0.03 & 0.37 & 0.01 & 0.36 & 0.08 & 0.50 & 0.02 \\
\hline
\end{tabular}


Figure 1. Change (mean and SE) in growth rates measured with elutriate, metal or pesticide mixture additions relative to control (no addition) and expressed in percentage for Isochrysis galbana and Thalassiosira delicatula under (A) axenic and (B) xenic culture conditions. Positive and negative values (\%) correspond to, respectively, an increase and a decrease in growth rate relative to control. Asterisks denote a significant difference $(\mathrm{p}<0.05)$ between treatments and control.

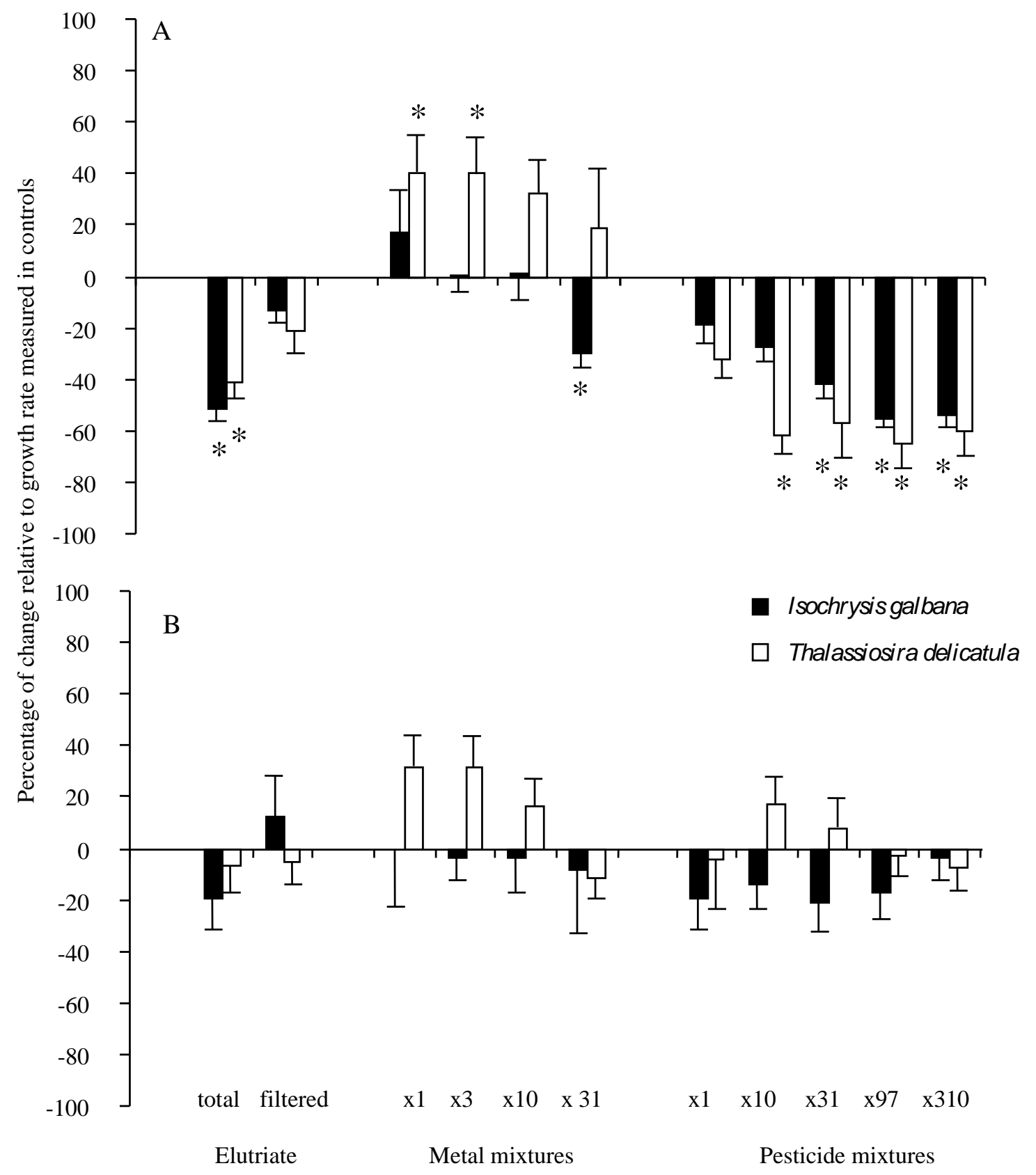


Figure 2. Bacterial diversity observed in xenic cultures of Thalassiosira delicatula and Isochrysis galbana and in the sediment elutriate: the dendrogram shows the clustering of bacterial communities found in cultures, based on Bray-Curtis similarities calculated at the OTU level and bar plots show the relative abundance of the main bacterial classes observed.

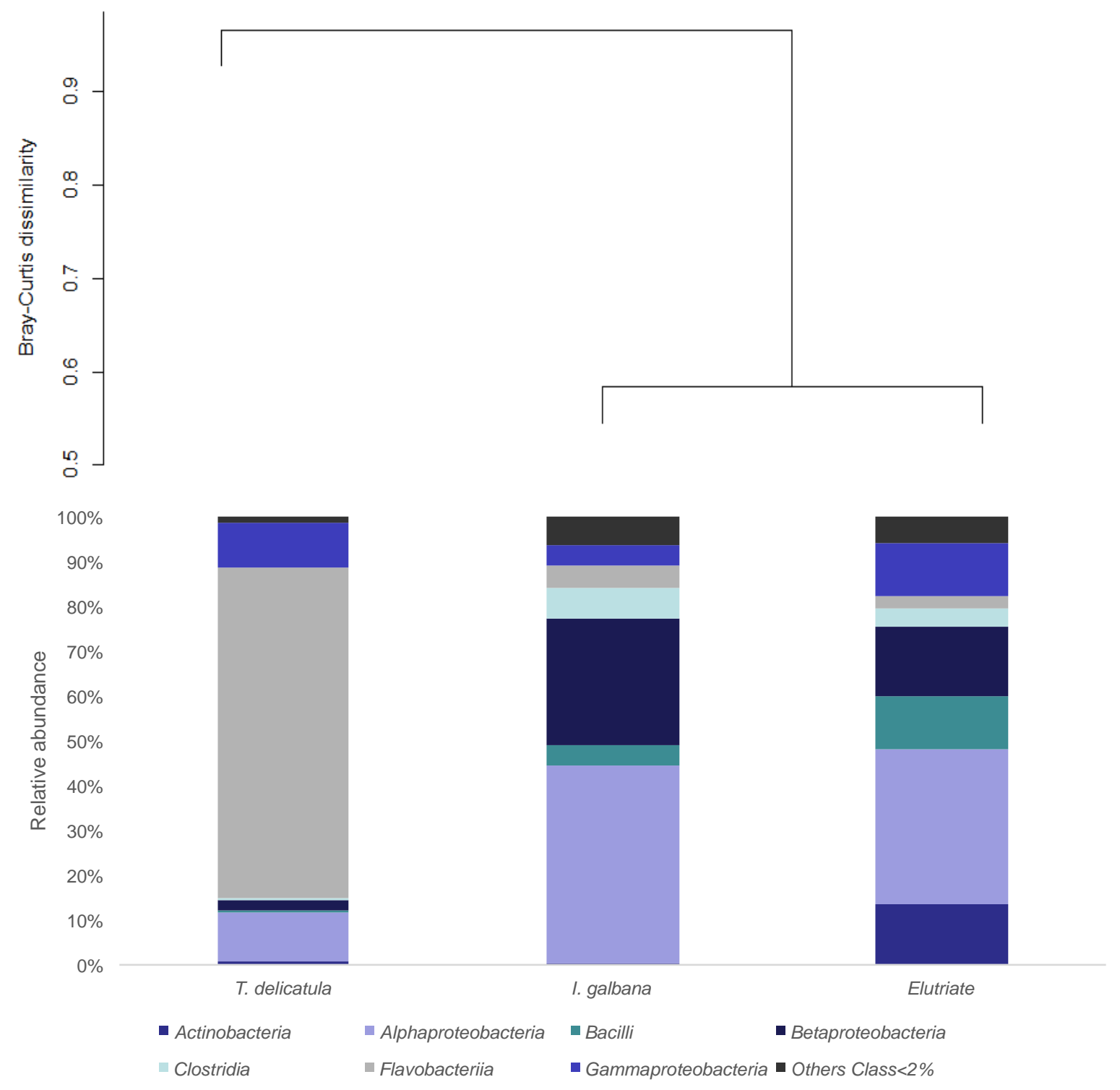

